\title{
WORK PROGRAM OF MADRASAH COMMITTEE
}

\author{
Isnaini Septemiarti \\ STAI Nurul Hidayah Selatpanjang, Riau, Indonesia \\ Email: isnainiseptemiarti@gmail.com \\ Widia Yunita \\ STAI Hubbulwathan Duri, Riau, Indonesia \\ Email: widiayunita136@gmail.com \\ DOI: $10.35445 /$ alishlah.v11i2.159
}

Accepted: November $20^{\text {th }}, 2019$. Approved: December $28^{\text {th }}, 2019$. Published:

December 30th, 2019

\begin{abstract}
This study aims to determine the role of the madrasah committee in improving the quality of madrasah. This research is a qualitative descriptive study. The subjects in this study were the head of the madrasah and the madrasah committee. While the object of this research is the work program of the MTsN 2 Siak madrasah committee for the 2018/2019 academic year. The number of samples in this study were 13 people consisting of 1 madrasah principal and 12 madrasah committees. Data obtained through interviews, observation, and documentation. The results showed that the madrasah committee had played its role and function as a provider of consideration, support and mediator. In the relationship between the head of madrasah and the madrasah committee, it can be linked as coordinative, supportive, evaluative, normative, collaborative, and communicative.
\end{abstract}

Keywords: madrasah committee, quality of madrasah, head of madrasah

\section{PROGRAM KERJA KOMITE MADRASAH}

\begin{abstract}
Abstrak
Penelitian ini bertujuan untuk mengetahui peranan komite madrasah dalam meningkatkan mutu madrasah. Penelitian ini merupakan penelitian deskriptif kualitatif. Subyek pada penelitian ini adalah kepala madrasah dan komite madrasah. Sedangkan obyek dari penelitian ini adalah program kerja komite madrasah MTsN 2 Siak Tahun Ajaran 2018/2019. Jumlah sampel dalam
\end{abstract}


Al-Ishlah: Jurnal Pendidikan - ISSN: 2087-949o (p); 2597-940X (e)

Vol.11, No.2 (2019)

penelitian ini adalah 13 orang yang terdiri dari 1 orang kepala madrasah dan 12 orang komite madrasah. Data diperoleh melalui wawancara, observasi, dan dokumentasi. Hasil penelitian menunjukkan bahwa komite madrasah telah melakukan peranan dan fungsinya sebagai pemberi pertimbangan, pendukung, dan mediator. Dalam tata hubungan kepala madrasah dengan komite madrasah dapat dihubungkan sebagai koordinatif, suportif, evaluatif, normatif, kolaboratif, dan komunikatif.

Kata Kunci : Komite madrasah, mutu madrasah, kepala madrasah

\section{PENDAHULUAN}

Pendidikan memegang peran yang sangat penting dalam proses peningkatan kualitas sumber daya manusia dan merupakan suatu proses yang sangat terintergrasi dengan peningkatan kualitas sumber daya manusia itu sendiri. Salah satu permasalahan pendidikan yang di hadapi oleh bangsa Indonesia adalah rendahnya mutu pendidikan di setiap jenjang pendidikan. Khususnya pendidikan dasar dan menengah, (Sanjaya, 2010). Berbagai usaha telah di lakukan untuk meningkatkan mutu pendidikan nasional, antara lain melalui usaha berbagai pelatihan dan peningkatan kompetensi guru, pengadaan buku dan alat pelajaran, perbaikan sarana dan prasarana pendidikan, dan dengan meningkatkan manajemen sekolah, (Sujanto, 2007).

Keselarasan antara kemajuan ilmu pengetahuan, teknologi dan informasi dengan tuntutan perkembangan masyarakat terhadap kualitas pelayanan serta hasil pendidikan menuntut adanya perubahan manajemen madrasah menjadi manajemen yang dilandasi kesepakatan, komitmen dan kesadaran membangun budaya baru dalam mewujudkan masyarakat madrasah yang memiliki loyalitas pada peningkatan mutu madrasah dan penyelenggaraan pendidikan yang akuntabel. Untuk mewujudkan masyarakat madrasah sesuai dengan manajemen berbasis madrasah, maka stakeholder pendidikan sebagai pihak yang terkait dengan proses pendidikan yaitu wali murid, masyarakat dan pihak madrasah harus saling bekerja sama, memiliki beban dan tanggung jawab yang seimbang dan proposional dalam pengambilan kebijakan dan penyelenggaraan proses pembelajaran serta pengajaran untuk meningkatkan mutu madrasah.(Umam, 2019).

Agar tidak menjadi tumpang tindih beban dan tanggung jawab diantara stakeholder pendidikan, maka yang diperlukan suatu lembaga yang independen, demokratis, transparan yang dapat di percaya oleh seluruh lapisan masyarakat. Untuk mewadahi Peran dan tanggung jawab serta wewenang yang seimbang dan proporsional antara madrasah, wali murid dan masyarakat serta stakeholder lainnya, maka untuk itu dibentuklah Komite Madrasah. Komite madrasah 
Al-Ishlah: Jurnal Pendidikan - ISSN: 2087-949o (p); 2597-940X (e)

Vol.11, No.2 (2019)

merupakan nama baru pengganti Badan Pembantu Penyelenggara Pendidikan (BP3). Secara substansional kedua istilah tersebut tidak begitu mengalami perbedaan. Hal yang membedakan hanya terletak pada pengoptimalan peran serta masyarakat dalam mendukung dan mewujudkan mutu pendidikan, keanggotaannya serta pemilihan dan pembentukan kepengurusan. (Fattah: 2004, Syarifudin: 2005)

Komite Madrasah adalah badan mandiri yang mewadahi peran serta masyarakat dalam rangka meningkatkan mutu, pemerataan, dan efisiensi pengelolaan pendidikan di satuan pendidikan madrasah maupun jalur pendidikan luar madrasah. Menurut UU RI Nomor 20 Tahun 2003 tentang Sistem Pendidikan Nasional, komite sekolah/madrasah adalah lembaga mandiri yang beranggotakan orang tua/wali peserta didik, komunitas madrasah, serta tokoh masyarakat seperti ulama/rohaniwan, budayawan, pemuka adat, pakar atau pemerhati pendidikan, wakil organisasi masyarakat, wakil dunia usaha dan industri, bahkan kalau perlu juga wakil siswa, wakil guru - guru, dan kepala Madrasah. Dengan demikian Komite Madrasah adalah suatu lembaga/badan mandiri yang terdiri dari sekumpulan orang - orang yang mempunyai suatu tugas untuk membantu pendidikan di madrasah misalnya membantu biaya operasional, membangun gedung madrasah, dan sarana serta prasarana pendidikan yang lain. Komite madrasah juga mewadahi masyarakat sekitar dalam meningkatkan mutu, pemerataan, dan efisiensi pengelolaan pendidikan madrasah maupun jalur pendidikan luar madrasah. Para pengurus komite madrasah biasanya berasal dari masyarakat sekitar yang bekerjasama dengan guru madrasah misalnya alumni, tokoh masyarakat, tokoh pendidikan, pengusaha, dan unsur - unsur lainnya.(Pandjastuti: 2008, Mulyasa: 2007, Suryosubroto: 2004).

Penelitian ini di fokuskan pada kajian tentang bagaimana pengertian komite madrasah, fungsi dan peran komite madrasah, dan hubungan sinergis komite madrasah dengan kepala madrasah. Kajian ini penting dilakukan sebagai upaya menciptakan kondisi yang kondusif di dalam pelaksanaan pendidikan di lingkungan madrasah. Hasil akhir yang ingin dicapai dengan adanya kondisi kondusif tersebut adalah peningkatan kualitas pendidikan.

\section{METODE PENELITIAN}

Penelitian ini merupakan penelitian kualitatif deskriptif. Penelitian dilakukan di MTsN 2 Siak, Riau. Subyek pada penelitian ini adalah kepala madrasah dan komite madrasah. Sedangkan obyek dari penelitian ini adalah program kerja komite madrasah MTsN 2 Siak Tahun Ajaran 2018/2019. Jumlah sampel dalam penelitian ini adalah 13 orang yang terdiri dari 1 orang kepala madrasah dan 12 orang komite madrasah. Data diperoleh melalui wawancara, 
Al-Ishlah: Jurnal Pendidikan - ISSN: 2087-949o (p); 2597-940X (e)

Vol.11, No.2 (2019)

observasi, dan dokumentasi. Setelah mengadakan penelitian dan semua data yang diperlukan telah terkumpul, kemudian data tersebut diolah dan dianalisis. Langkah berikutnya adalah menyimpulkan. Langkah-langkah yang penulis tempuh dalam penelitian ini adalah secara kualitatif (peneliti tidak mengadakan perhitungan atau tidak menggunakan bilangan atau frekuensi symbol dalam melakukan analisa).

\section{HASIL DAN PEMBAHASAN}

Dalam pembentukan komite madrasah, pihak madrasah mengundang wali murid, di mana komite tersebut berasal dari wali murid, biasanya pengundangan wali murid untuk pembentukan komite madrasah di adakan di awal tahun ajaran baru yang tujuannya adalah untuk membuat program pendidikan yang akan dilaksanakan oleh pihak madrasah. Komite madrasah mengetahui dan membantu dalam pelaksanaannya. Pemilihan komite madrasah memang harus mengacu kepada kriteria yang sudah ditetapkan diantaranya adalah luwes, cakap dan berdedikasi tinggi serta loyal dengan sekolah. Komite madrasah yang akan terpilih juga orang-orang yang dekat dengan masyarakat.

Pemilihan komite madrasah yang dilaksanakan di MTsN 2 Siak berjalan dengan lancar, karena pihak madrasah sudah merencanakan terlebih dahulu serta telah membuat program-program pendidikan untuk masa yang akan datang. Sebelum pemilihan komite madrasah, pihak madrasah membagikan buku pegangan komite, kepada setiap perwakilan, buku pegangan ini berisikan tentang peran, fungsi dan tujuan komite madrasah dibentuk.

Dari hasil wawancara dengan kepala madrasah, diperoleh informasi dalam pembentukan komite madrasah di MTsN 2 Siak telah melibatkan masyarakat setempat. Masyarakat di undang untuk pembentukan komite madrasah beserta perangkatnya untuk bekerjasama dengan pihak sekolah untuk mencapai tujuan pendidikan dan meningkatkan mutu pendidikan. Masyarakat di sekitar madrasah sangat antusias sekali terhadap tujuan madrasah. Masyarakat siap bekerjasama dengan pihak madrasah untuk menghasilkan siswa-siswa yang bermutu dan berkompetensi.

Komite madrasah merupakan penyalur aspirasi masyarakat, maka dalam membuat program madrasah, komite selalu diundang untuk menyempurnakan program tersebut. Madrasah membuat jadwal tertulis untuk mengundang komite madrasah. Rapat diadakan sekali sebulan dengan komite sekolah. Dalam pelaksanaan rapat, komite selalu mendengarkan aspirasi masyarakat dan menyampaikan kepada pihak madrasah. Komite selalu menilai kegiatan belajar di sekolah dan selalu memberikan masukan kepada sekolah tentang kegiatan pembelajaran siswa. Dalam membuat program pendidikan, madrasah dan komite 
Al-Ishlah: Jurnal Pendidikan - ISSN: 2087-949o (p); 2597-940X (e)

Vol.11, No.2 (2019)

selalu bekerjasama, komite memberikan usulan-usalan untuk meningkatkan mutu pendidikan. Madrasah selalu bermusyawarah dengan komite tentang pendidikan siswa kedepannya. Dari hasil wawancara di atas dapat peneliti simpulkan bahwa komite madrasah sebagai penyalur aspirasi masyarakat di MTsN 2 Siak sudah terlaksana. Komite selalu mendapatkan informasi dari masyarakat tentang kondisi anak mereka dalam menambah ilmu di madrasah dan masyarakat selalu memberikan laporan kepada madrasah mengenai tingkah laku anak-anak mereka. Komite madrasah juga mendapatkan informasi dari masyarakat tentang apa yang dibutuhkan anak mereka dalam belajar.

Komite juga membuat program untuk pelaksanaan pendidikan. Program tersebut di sampaikan kepada pihak madrasah. Madrasah menanggapi program komite tersebut dan menyempurnakan program komite bersama-sama. Komite madrasah menjalankan program yang sudah disepakati. Komite madrasah selalu memantau kegiatan madrasah setiap ada kegiatan. Komite madrasah selalu mengawasi serta memberikan layanan masyarakat terhadap pelaksanaan program komite. Komite selalu mendatangi madrasah jika pihak madrasah membutuhkan, sehingga segala kegiatan madrasah selalu di awasi oleh komite. Setiap di undang rapat komite madrasah selalu memberikan masukan untuk kemajuan pendidikan. Komite memikirkan untuk kemajuan madrasah dengan memberikan saran-saran yang membangun. Komite memiliki jadwal kunjungan tetap ke madrasah. Namun jika ada permasalahan atau ada yang ingin di sampaikan komite madrasah bisa kapan saja mengunjungi sekolah.

Kedatangan komite madrasah disesuaikan dengan urusannya. Jika berurusan dengan pihak madrasah, maka komite madrasah harus mengkonfirmasikan kedatangannya terlebih dahulu. Bisa saja komite madrasah datang atau berkunjung ke madrasah tanpa konfirmasi, misalnya melihat kegiatan proses belajar mengajar siswa, atau kedatangan komite madrasah melihat kondisi fasilitas-fasilitas sekolah. Komite selalu bekerjasama dengan pihak madrasah, setiap apa yang di programkan mereka selalu mendiskusikannya untuk mencari kata sepakat demi kemajuan pendidikan. Komite selalu mengawasi kegiatan pembelajaran di madrasah. Setiap ada kegiatan, komite sekolah selalu dilibatkan sebagai penanggung jawab. Disamping mengawasi kegiatan pembelajaran, komite madrasah juga mengawasi fasilitas-fasilitas belajar dan aset madrasah yang lainnya. Komite madrasah bekerja bersama dengan anggota dan pihak madrasah demi kelangsungan proses pendidikan dan meningkatkan mutu pendidikan.

Komite madrasah memberi pertimbangan dalam penentuan dan pelaksanaan kebijakan pendidikan di satuan pendidikan dengan selalu mengacu kepada anggaran dasarnya. Komite memberi pertimbangan dalam penentuan dan pelaksanaan kebijakan pendidikan di satuan pendidikan dengan memberikan 
Al-Ishlah: Jurnal Pendidikan - ISSN: 2087-949o (p); 2597-940X (e)

Vol.11, No.2 (2019)

masukan kepada pihak sekolah atau membuat proposal bantuan kepada wali murid atau pihak-pihak yang terlibat dalam kemajuan pendidikan. Komite madrasah juga mengontrol transparansi dan akuntabilitas penyelenggaraan dan keluaran pendidikan di satuan pendidikan, dengan cara madrasah selalu melaporkan atau komite madrasah meminta laporan. Komite madrasah melakukan kerjasama dengan masyarakat dan pemerintah berkenaan dengan penyelenggaraan pendidikan yang bermutu dengan membuat proposal ke perorangan/organisasi/dunia usaha/dunia industry untuk kemajuan pendidikan.

Komite madrasah memberikan masukan, pertimbangan, dan rekomendasi kepada satuan pendidikan dengan cara selalu berkomunikasi dengan pihak madrasah dalam upaya memajukan pendidikan. Komite madrasah mendorong orang tua dan masyarakat berpartisipasi dalam pendidikan guna mendukung peningkatan mutu dan pemerataan pendidikan. Komite madrasah juga menggalang dana masyarakat dalam rangka pembiayaan penyelenggaraan pendidikan di satuan pendidikan. Pada akhir kegiatan dilakukan evaluasi dan pengawasan terhadap kebijakan, program, penyelenggaraan, dan keluaran pendidikan di satuan pendidikan.

Dari hasil observasi dan wawancara di atas dapat di simpulkan bahwa hubungan madrasah dengan komite terjalin dengan baik, karena komite selalu di libatkan dalam kegiatan pendidikan. Manshur (2017) menyatakan bahwa peran komite madrasah yang harus dilaksanakan adalah sebagai pemberi pertimbangan, pendukung, pengontrol, dan mediator antara pemerintah dengan masyarakat. Berikut adalah indikator peran komite madrasah:

Tabel 1. Indikator Peran Komite Madrasah

\begin{tabular}{|c|c|c|}
\hline $\begin{array}{c}\text { Peran Komite } \\
\text { Madrasah }\end{array}$ & Fungsi Manajemen & Indikator kinerja \\
\hline \multirow[t]{3}{*}{$\begin{array}{l}\text { Sebagai badan } \\
\text { pertimbangan (advisory } \\
\text { agency) }\end{array}$} & Perencanaan Madrasah & $\begin{array}{ll}\text { a. } & \text { Identifikasi sumber daya pendidikan } \\
\text { dalam masyarakat } \\
\text { b. Memberikan masukan RAPBS } \\
\text { c. Menyelenggarakan rapat RAPBS } \\
\text { d. Memberikan pertimbsngsn } \\
\text { perubahan RAPBS } \\
\text { e. Ikut mensahkan RAPBS bersama kepala } \\
\text { Madrasah }\end{array}$ \\
\hline & $\begin{array}{l}\text { Pelaksanaan program } \\
\text { Kurikulum } \\
\text { PBM } \\
\text { Penilaian } \\
\end{array}$ & $\begin{array}{l}\text { Memberikan masukan terhadap proses } \\
\text { pengelolaan pendidikan di Madrasah } \\
\text { b. Memberikan masukan terhadap proses } \\
\text { pembelajaran kepada guru- guru }\end{array}$ \\
\hline & $\begin{array}{l}\text { Pengadan Sumber Daya } \\
\text { Pendidikan (SDM, S/P, } \\
\text { Anggaran }\end{array}$ & $\begin{array}{l}\text { a. Identifikasi potensi } \\
\text { sumberdaya pendidikan dalam } \\
\text { masyarakat } \\
\text { b. Memberikan pertimbangan tentang tenaga }\end{array}$ \\
\hline
\end{tabular}


Al-Ishlah: Jurnal Pendidikan - ISSN: 2087-949o (p); 2597-940X (e)

Vol.11, No.2 (2019)

\begin{tabular}{|c|c|c|c|}
\hline & & c. & $\begin{array}{l}\text { kependidikan yang dapat diperbantukan } \\
\text { di Madrasah } \\
\text { Memberikan pertimbangan tentang } \\
\text { anggaran yang dapat dimanfaatkan di } \\
\text { Madrasah }\end{array}$ \\
\hline \multirow[t]{3}{*}{$\begin{array}{l}\text { Sebagai bahan } \\
\text { pendukung (Supporting } \\
\text { Agency) }\end{array}$} & Sumber daya & $\begin{array}{l}\text { b. } \\
\text { c. }\end{array}$ & $\begin{array}{l}\text { Pemantauan terhadap kondisi ketenagaan } \\
\text { pendidikan di Madrasah } \\
\text { Mobilitas guru sukarelawan di Madrasah } \\
\text { Mobilitas tenaga kependidikan non } \\
\text { guru di Madrasah }\end{array}$ \\
\hline & Sarana dan prasarana & $\begin{array}{l}\text { a. } \\
\text { b. } \\
\text { c. }\end{array}$ & $\begin{array}{l}\text { Mobilitas bantuan sarana dan prasarana } \\
\text { di Madrasah } \\
\text { Koordinasi dukungan sarana dan } \\
\text { prasarana di Madrasah } \\
\text { Evaluasi pelaksanaan dukungan }\end{array}$ \\
\hline & Anggaran & $\begin{array}{l}\text { a. } \\
\text { b. } \\
\text { c. } \\
\text { d. }\end{array}$ & $\begin{array}{l}\text { Memantau kondisi anggaran } \\
\text { pendidikan di Madrasah } \\
\text { Mobilitas dukungan terhadap anggaran } \\
\text { pendidikan di Madrasah } \\
\text { Koordinasi dukungan terhadap anggaran } \\
\text { pendidikan di Madrasah } \\
\text { Evalusi pelaksanaan dukungan } \\
\text { anggaran di Madrasah }\end{array}$ \\
\hline \multirow[t]{3}{*}{$\begin{array}{l}\text { Sebagai badan } \\
\text { pengontrol }\end{array}$} & $\begin{array}{l}\text { Kontrol terhadap } \\
\text { perencanaan Madrasah }\end{array}$ & $\begin{array}{l}\text { a. } \\
\text { b. }\end{array}$ & $\begin{array}{l}\text { Pengawasan terhadap proses pengambilan } \\
\text { keputusan di Madrasah } \\
\text { Penilaian terhadap kualitas kebijakan } \\
\text { di Madrasah } \\
\text { Pengawasan terhadap proses perencanaan } \\
\text { Madrasah } \\
\text { Pengawasan terhadap kualitas } \\
\text { perencanaan Madrasah } \\
\text { Pengawasan }\end{array}$ \\
\hline & $\begin{array}{l}\text { Kontrol terhadap } \\
\text { pelaksanaan } \\
\text { program Madrasah }\end{array}$ & $\begin{array}{l}\text { a. } \\
\text { b. }\end{array}$ & $\begin{array}{l}\text { Pengawasan terhadap organisas isekoah } \\
\text { Pengawasan terhadap } \\
\text { penjadwalan program Sekoah } \\
\text { Pengawasan terhadap alokasi } \\
\text { anggaran untuk pelaksanaan program } \\
\text { Madrasah } \\
\text { Pengawasan terhadap sumber } \\
\text { daya pelaksanaan program Madrasah } \\
\text { Pengawasaan terhadap Peran } \\
\text { Madrasah terhadap program Madrasah. }\end{array}$ \\
\hline & $\begin{array}{l}\text { Kontrol terhadap out } \\
\text { put pendidikan }\end{array}$ & $\begin{array}{l}\text { a. } \\
\text { b. } \\
\text { c. }\end{array}$ & $\begin{array}{l}\text { Penilaian terhadap hasil ujian nasional } \\
\text { Penilaian terhadap angka Peran Madrasah } \\
\text { Penilaian terhadap angka } \\
\text { mengulang Madrasah } \\
\text { Penilaian terhadap angka } \\
\text { bertahun Madrasah }\end{array}$ \\
\hline
\end{tabular}


Al-Ishlah: Jurnal Pendidikan - ISSN: 2087-949o (p); 2597-940X (e)

Vol.11, No.2 (2019)

Mediator agency Perencanaan a. Menjadi penghubung antar KS dengan masyarakat, KS dengan dewan pendidikan, serta KS dengan Madrasah

b. Identifikasi aspirasi pendidikan dalam masyarakat

c. Membuat usulan kebijakan dan program pendidikan kepada Madrasah

Pelaksanaan program

Sumber daya
a. Sosialisai kebijakan dan program pendidikan Madrasah terhadap masyarakat
b. Memfasilitasi berbagai masukan terhadap kebijakan program terhadap Madrasah
c. Menampung pengaduan dan keluhan terhadap kebijakan dan program pendidikan
d. Mengkomunikasokan pengaduan dan keluhan masyarakat terhadap instansi terkait dalam
e. bidang pendidikan Madrasah
a. Identifikasi kondisi sumber daya Madrasah
b. Identifikasi sumber daya masyarakat
c. Mobilisasi bantuan masyarakat untuk pendidikan Madrasah
d. Koordinasi bantuan masyarakat.

\section{SIMPULAN}

Komite madrasah adalah badan mandiri yang mewadahi peran serta masyarakat dalam rangka meningkatkan mutu, pemerataan, dan efisiensi pengelolaan pendidikan di satuan pendidikan. Peranan komite madrasah secara kontekstual adalah pemberi pertimbangan, pendukung, dan mediator. Dalam tata hubungan kepala madrasah dengan komite madrasah dapat dihubungkan sebagai koordinatif, suportif, evaluatif, normatif, kolaboratif, dan komunikatif.

\section{DAFTAR PUSTAKA}

Bedjo, Sujanto. (2007). Manajemen Pendidikan Berbasis Sekolah; Model Pengelolaan Sekolah Di Era Otonomi. Jakarta : Sagung Seto.

Dachnel Kamars. (2005). Administrasi Pendidikn Teori dan Praktek. Padang : Universitas Putra Indonesia Press. 
Al-Ishlah: Jurnal Pendidikan - ISSN: 2087-949o (p); 2597-94oX (e)

Vol.11, No.2 (2019)

Departemen Pendidikan Nasional. (2003). Undang-undang Nomor 20 tahun 2003 tentang Sistem Pendidikan Nasional. Jakarta

Ismail, F. (2018). Manajemen Berbasis Sekolah: Solusi Peningkatan Kualitas Pendidikan. Jurnal Ilmiah Iqra', 2(2).

Kepmendiknas nomor: 044/U/2002. Tentang Dewan Pendidikan dan Komite Sekolah

Manshur, A. (2017). Peran komite madrasah dan kepemimpinan kepala madrasah dalam meningkatkan mutu pendidikan islam. Jurnal Keislaman, Vol6, hal 37 -38 .

Mulyasa. (2007). Menjadi Kepala Sekolah Profesional. Jakarta:Rosda Karya.

Nanang Fattah. (2004). Manajemen Berbasis Sekolah dan Dewan Sekolah. Bandung : Pustaka Bani Quraisy

Pantjastuti, S.R. (2008). Komite Sekolah: Sejarah dan Prospeknya di Masa Depan. Yogyakarta: Hikayat.

Sanjaya, Wina. (2010). Strategi Pembelajaran Berorientasi Standar Proses Pendidikan: Jakarta : Kencana.

Syafaruddin. (2005). Manajemen Lembaga Pendidikan Islam. Jakarta : Ciputat Press.

Suryosubroto. (2004). Manajemen pendidikan sekolah. Jakarta: Rineka cipta.

Umam, M.K. (2019). Komite Madrasah dalam Konteks Manajemen Mutu Terpadu Pendidikan Islam. Jurnal Al-Hikmah, 7(1): 39-56. 